\title{
ANALISIS PENYALURAN KREDIT KONSUMSI PADA PERBANKAN DI INDONESIA TAHUN 2004 - 2010
}

\author{
Oleh: \\ Oktavia Hartika \\ PT. Bank Mandiri Tbk. \\ oktahartika@yahoo.co.id
}

\begin{abstract}
The research objective was to determine the influence of third party fund, Nonperfoming loans (NPLs), Capital Adequacy Ratio (CAR) on consumer loans disbursed. The analytical tool used panel data regression. The sample used in this study are 7 (seven) bank based on the type of operation. Results of regression, found that variable third party fund positive and significant impact on consumer loans. Variable Non-perfoming loans (NPLs) and not significant positive effect on consumer loans. This is possible due to high NPLs in the bank's financial statements only describe the overall value of the credit. Capital Adequacy Ratio (CAR) individually have a significant negative effect on consumer loans. The study reinforces previous findings that high capital still has not been followed by increased consumer credit.
\end{abstract}

Keywords: Consumer Credit, Third Party Fund, Non-perfoming loans (NPLs), Capital Adequacy Ratio (CAR).

\begin{abstract}
ABSTRAK
Tujuan penelitian adalah untuk mengetahui pengaruh Dana Pihak Ketiga (DPK), Non Perfoming Loan (NPL), Capital Adequacy Ratio (CAR) terhadap kredit konsumsi yang disalurkan. Alat analisis yang digunakan regresi data panel. Sampel yang di gunakan dalam penelitian ini adalah 7 (tujuh) bank berdasarkan jenis operasionalnya. Hasil dari regresi, diperoleh bahwa variabel Dana Pihak Ketiga (DPK) berpengaruh positif dan signifikan terhadap kredit konsumsi. Variabel Non Perfoming Loan (NPL) berpengaruh positif dan tidak signifikan terhadap kredit konsumsi. Hal ini di mungkinkan mengingat tingginya NPL dalam laporan keuangan bank hanya menggambarkan nilai keseluruhan kredit. Capital Adequacy Ratio (CAR) secara individual mempunyai pengaruh negatif dan signifikan terhadap kredit konsumsi. Penelitian ini memperkuat temuan sebelumnya bahwa tingginya permodalan masih belum diikuti oleh meningkatnya kredit konsumsi.
\end{abstract}

Kata Kunci : Kredit Konsumsi, Dana Pihak Ketiga (DPK), Non Perfoming Loan (NPL), Capital Adequacy Ratio (CAR). 


\section{PENDAHULUAN}

Kredit merupakan sumber pendapatan bagi bank yang bertujuan untuk meningkatkan pembangunan ekonomi dan menunjang sektor rill. Salah satunya adalah kredit konsumsi yang saat ini memberikan risiko kredit yang kecil di banding kredit modal kerja dan kredit investasi. Kredit konsumsi menjadi sasaran bank karena di lihat dari jumlah rumah tangga, objeknya yang banyak dan kredit konsumsi sering dikaitkan oleh kolateral yang kuat, sehingga bank meminimkan resiko terjadinya kredit macet. Kredit konsumsi ini berbeda dengan kredit investasi dan modal kerja yang lebih bersifat produktif, artinya dapat menghasilkan sesuatu keuntungan di kemudian hari, kredit konsumsi hanya bersifat sekali pakai, artinya barang-barang yang digunakan untuk konsumsi saja.

Pertumbuhan kredit konsumsi juga ditopang oleh fundamental Indonesia yang masih cukup kuat, terutama untuk jenis kredit perumahan dan kendaraan bermotor. Bahkan, jumlah kredit konsumsi lebih besar dari kredit modal kerja dan kredit investasi. Tetapi, Kenaikan kredit konsumsi yang tidak terawasi dapat berakibat buruk terhadap perekonomian, terutama apabila pihak bank tidak mampu menilai dengan baik potensi atau kemampuan membayar dari seorang debitur sehingga dapat mengganggu stabilitas keuangan (financial stability) Indonesia dan dapat menyebabkan inflasi, apabila sektor produksi tidak berjalan dengan baik. (Hutagulung dan Nasution:2013)

Perkembangan kredit perbankan selama beberapa tahun ini menunjukkan kinerja yang membaik sejalan dengan perkembangan kondisi ekonomi makro di Indonesia. Hal ini ditunjukkan dengan indikator-indikator utama perbankan yang terus menunjukkan tanda-tanda membaik, seperti LDR (Loan to Deposit Ratio), NPL (Non Performing Loan), profitabilitas dan CAR (Capital Adequacy Ratio). LDR perbankan cenderung meningkat meskipun masih berada di sekitar 50\%, sementara NPL terus menurun meskipun belum mencapai angka di bawah 5\% sebagaimana yang diinginkan Bank Indonesia. 
Dari permasalahan di atas, maka pembahasan ini akan menguji pengaruh variabel - variabel bebas yang meliputi Dana Pihak Ketiga (DPK), Non Perfoming Loan (NPL), Capital Adequacy Ratio (CAR) terhadap variabel terikat jumlah Kredit konsumsi.

\section{METODOLOGI PENELITIAN.}

Lokasi pengambilan data secara tidak langsung melalui media perantara yaitu Statistik Perbankan Indonesia (SPI) yang di terbitkan oleh Bank Indonesia. Populasi dalam penelitian ini adalah sebanyak 7 bank berdasarkan data Statistik Perbankan Indonesia (SPI). Populasinya adalah Bank Umum, Bank Persero, Bank Devisa, Bank Non Devisa, Bank Pembangunan Daerah, Bank Campuran, Bank Asing. Sedangkan yang di gunakan sebagai sampel penelitian adalah seluruh bank tersebut yang di jadikan pupulasi.

Analisis dilakukan dengan mengunakan metode regresi linier berganda dengan data panel, langkah pertama dengan melakukan teknik estimasi regresi data panel melalui uji statistic $F$, uji langrange multiplier (LM), dan uji hausman ketiga teknik tersebut digunakan untuk memilih model yang paling bagus. Langkah kedua dengan melakukan uji hipotesis melalui uji signifikansi parameter secara serentak (Uji F), uji signifikansi parameter individual (Uji t), dan koefisien determinasi $\left(\mathrm{R}^{2}\right)$ ketiga uji tersebut dilakukan untuk melihat pengaruh variabel bebas terhadap variabel terikat.

\section{PEMBAHASAN}

Memperhatikan kembali penyaluran kredit konsumsi di Indonesia setiap tahunnya mengalami peningkatan dan penurunan. Berdasarkan grafik 1 dapat diketahui rata - rata distribusi penyaluran kredit konsumsi terbesar pada Bank umum sebesar 5,46\%. Sedangkan rata- rata penyalurun kredit konsumsi terkecil oleh Bank campuran sebesar 3,62 \%. Kebutuhan rumah tinggal dan konsumsi masyarakat yang sangat tinggi, menjadikan bank umum menargetkan pembiayaan untuk sektor kredit konsumsi sangat besar. Sehingga bank umum menjadi bank 
penyalur terbesar untuk kredit konsumsi. Bank campuran di hadapkan pada tantangan yang tidak ringan sebagai akibat dari krisis surat utang subprime mortgage di Amerika Serikat yang mendorong terjadinya gejolak di pasar uang internasional dan meningkatnya harga minyak dunia, sehingga berakibat menurunnya konsumsi masyarakat. Maka, dapat kita amati pada grafik di bawah ini:

\section{Gambar 1. Rata - Rata Penyaluran Kredit Konsumsi Perbankan Di Indonesia Tahun $2004-2010$}

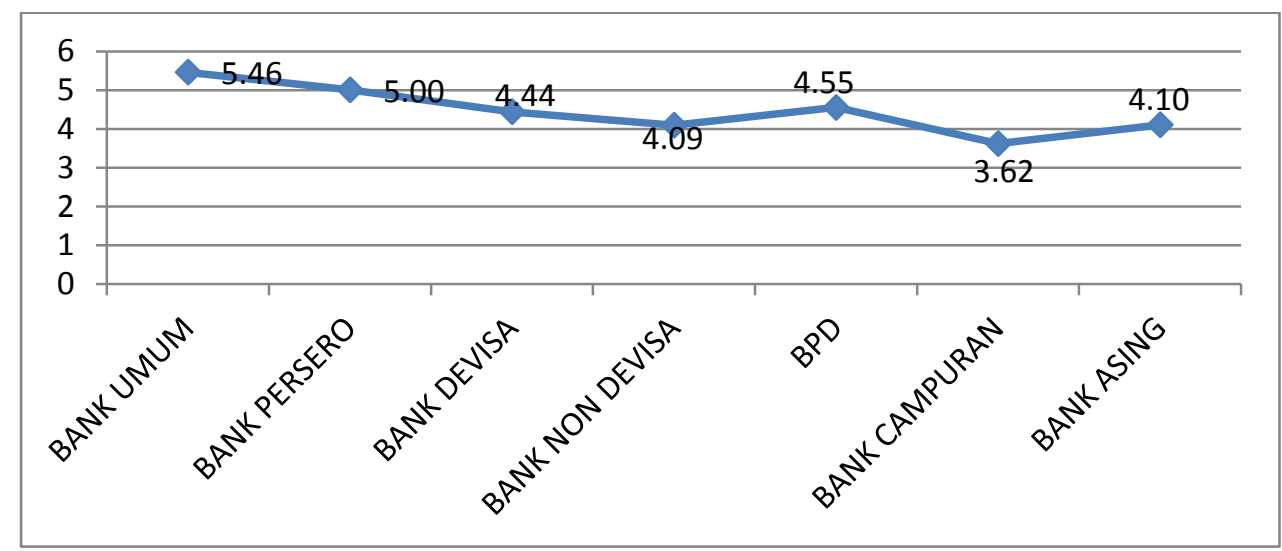

Sumber: Statistik Perbankan Indonesia (Data Diolah, 2014)

Distribusi Dana Pihak Ketiga (DPK) setiap tahunnya mengalami peningkatan dan penurunan. Berdasarkan grafik 2 dapat diketahui rata - rata distribusi Dana Pihak Ketiga (DPK) terbesar oleh Bank umum sebesar $6,17 \%$. Sedangkan rata- rata distribusi penyalurun kredit konsumsi terkecil oleh Bank Non Devisa sebesar 4,06 \%. Kondisi makroekonomi yang kurang baik, karena pemerintah menaikkan harga BBM yang menyebabkan tingginya inflasi. Akibat tingginya inflasi ini maka Bank Non Devisa menaikkan suku bunga kredit dan tabungannya. Bank Umum menjadi Bank dengan Dana Pihak Ketiga tertinggi karena Bank umum telah melakukan penghimpunan Dana Pihak Ketiga secara optimal dengan melakukan program reward yang menarik, sales people, dan services people yang qualitified, suku bunga simpanan yang menarik, dan jaringan layanan yang luas untuk menarik minat 
masyarakat untuk menyimpan menghasilkan laba bagi Bank dananya dan penyaluran kredit Umum. Maka, dapat kita amati pada konsumsi merupakan alokasi Dana grafik di bawah ini:

Pihak Ketiga paling utama dalam

Grafik 2. Rata - Rata Dana Pihak Ketiga Di Indonesia Tahun 2004 - 2010

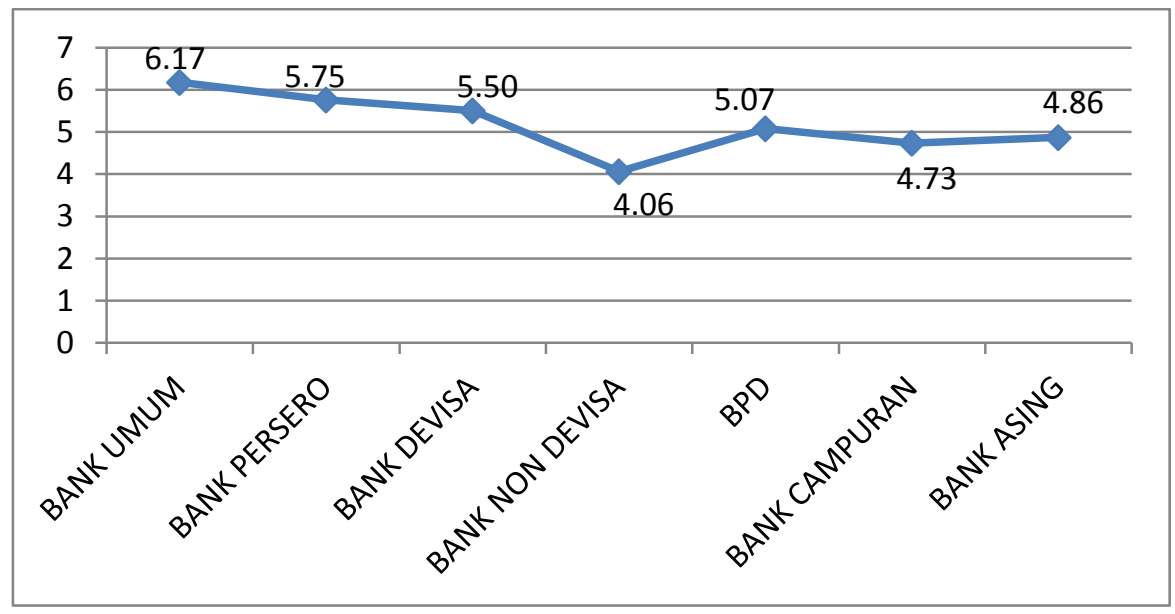

Sumber: Statistik Perbankan Indonesia (Data Diolah, 2014)

Distribusi Non Perfoming Loan (NPL) setiap tahunnya mengalami peningkatan dan penurunan. Berdasarkan grafik 3 dapat diketahui rata - rata distribusi Non Perfoming Loan (NPL) terbesar oleh Bank persero sebesar 6,83\%. Pada tahun 2005 pemerintah menaikkan harga BBM yang menyebabkan tingginya inflasi sehingga Bank Persero menaikkan suku bunga kredit. Tingginya suku bunga ini membuat masyarakat dan perusahaan mengalami kesulitan untuk mendapatkan kredit dari perbankan sehingga fungsi intermediasi perbankan tidak berjalan semestinya. Sedangkan rata- rata distribusi Non Perfoming Loan (NPL) terkecil oleh Bank Pembangunan Daerah sebesar 1,72 \%. Karena Bank Pembangunan Daerah banyak melibatkan APBD sebagai captive market sehingga NPL tetap berada dalam kondisi aman. Maka, dapat kita amati pada grafik di bawah ini: 
Grafik 3 Rata - Rata Non Perfoming Loan (NPL) Di Indonesia Tahun 2004 $-2010$

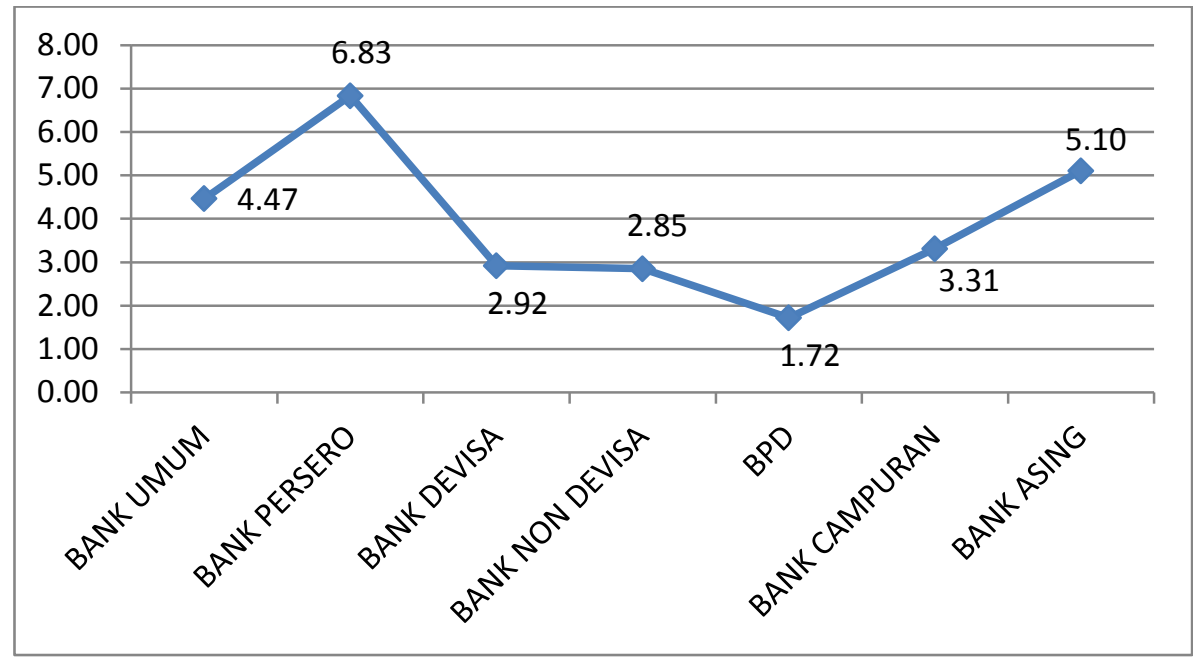

Sumber: Statistik Perbankan Indonesia (Data Diolah, 2014)

Distribusi Capital Adequacy peluang akan hal tersebut. Ratio (CAR) setiap tahunnya mengalami peningkatan dan penurunan. Berdasarkan grafik 4 dapat diketahui rata - rata distribusi Capital Adequacy Ratio (CAR) terbesar oleh Bank Campuran sebesar $27,7 \%$. disebabkan adanya transfer Dana Usaha yang cukup signifikan ditempatkan oleh kantor pusat bank asing tersebut, namun ditengarai transfer tersebut hanya Sedangkan rata- rata Capital untuk memenuhi ketentuan permodalan. Hal ini dimungkinakan karena Surat Keputusan Direksi Bank Indonesia No.32/37/KEP/DIR tanggal 14 Mei 1999 yang mengatur mengenai Dana Usaha membuka 


\section{Grafik 4. Rata - Rata Capital Adequacy Ratio (CAR) Di IndonesiaTahun $2004-2010$}

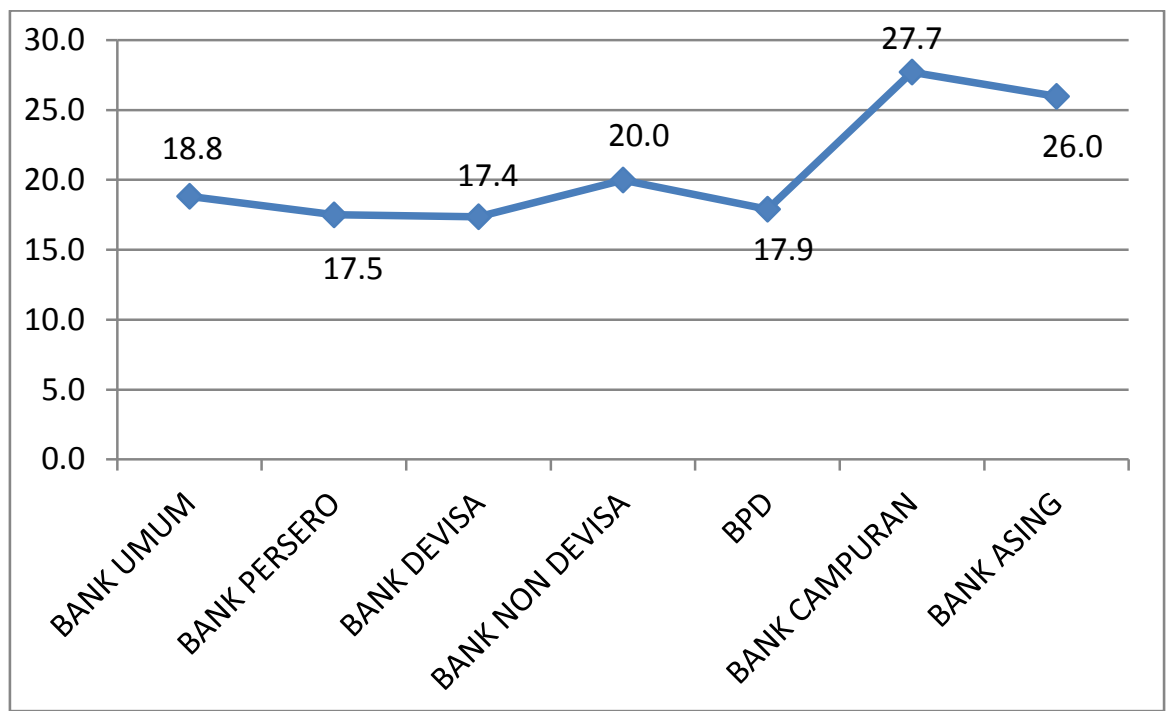

Sumber: Statistik Perbankan Indonesia (Data Diolah, 2014)

Dari hasil uji $\mathrm{F}$ diperoleh nilai $F_{\text {hitung }}=2.960288327$ jadi nilai $F_{\text {hitung }}$ $2.960288327>\mathrm{F}_{\text {tabel }} 2,84$ maka dapat disimpulkan bahwa Ho ditolak dan Ha diterima, berati model Fixed Effect Yang paling tepat.

Dari hasil uji LM diperoleh nilai $\mathrm{LM}_{\text {hitung }} 6428.15582>\mathrm{X}_{2} 12,8381$ maka dapat disimpulkan bahwa Ho ditolak dan Ha diterima, berati model Random Effect merupakan model yang tepat.
Dari hasil olah data Hausman hitung $_{\text {Hat }}$ 5.228074 jadi hausman hitung $5.228074<12,8381$ Maka dapat disimpulkan bahwa Ho diterima dan Ha ditolak, berati model Random Effect merupakan model yang paling tepat.

Perhitungan regresi yang di sajikan seperti dibawah ini:

Tabel 1. Hasil Analisis Regresi (Model Random Effect)

\begin{tabular}{ccccc}
\hline Variable & Coefficient & Std. Error & t-Statistic & Prob. \\
\hline C & 3.396229 & 0.989018 & 3.433939 & 0.0013 \\
\hline DPK? & 0.391486 & 0.156396 & 2.503176 & 0.0160 \\
\hline NPL? & 0.000628 & 0.037675 & 0.016663 & 0.9868
\end{tabular}

Tabel 1. Dilanjutkan pada halaman 38 
Lanjutan dari tabel 1 halaman 37

\begin{tabular}{ccccc}
\hline CAR? & -0.045952 & 0.021176 & -2.170056 & 0.0353 \\
\hline R-squared & 0.545223 & Mean dependent var & 4.468571 \\
\hline $\begin{array}{c}\text { Adjusted R- } \\
\text { squared }\end{array}$ & 0.514905 & S.D. dependent var & 0.753398 \\
\hline S.E. of regression & 0.524732 & Sum squared resid & 12.39048 \\
\hline Durbin-Watson stat & 2.328561 & & \\
\hline Sumber : Eviews (Data diolah) & &
\end{tabular}

Dari hasil uji signifikansi regresi

Data Panel, terpilih model Random

Effect sebagai model yang tepat dan

di peroleh model persamaan regresi

linier berganda sebagai berikut:

$$
\operatorname{LnY}_{\text {it }}=\beta_{\mathrm{i}} \operatorname{LnX} X_{\text {it }}+\beta_{2} X_{\text {it }}+\beta 3 X_{\text {it }} e_{\text {it }}
$$

Dari hasil Random Effect maka di peroleh :

$$
\begin{gathered}
\operatorname{LnY}_{\text {it }}=0.391486 \operatorname{LnX} X_{1}+ \\
0.000628 X_{2}-0.045952 X_{3}+e_{i t}
\end{gathered}
$$

B1(DPK): 0.391486 , koefisien regresi variabel Dana Pihak Ketiga $\left(\mathrm{X}_{1}\right)$ sebesar 0.391486. Berarti ada pengaruh positif antara Dana Pihak Ketiga (DPK) $\left(\mathrm{X}_{1}\right)$ terhadap Penyaluran Kredit Konsumsi (Y) sebesar 0.391486, Jika Dana Pihak Ketiga $\left(\mathrm{X}_{1}\right)$ naik sebesar sebesar $1 \%$, Maka penyaluran kredit konsumsi (Y) akan naik sebesar 39,14\% dan jika Dana Pihak Ketiga turun $\left(\mathrm{X}_{1}\right)$ turun sebesar $1 \%$ maka penyaluran Kredit Konsumsi (Y) akan turun sebesar 39,14 \% dengan asumsi variabel lainnya konstan yaitu NPL $\left(\mathrm{X}_{2}\right)$, CAR $\left(\mathrm{X}_{3}\right)$ tidak mengalami perubahan atau tetap (cateris paribus).

B1(NPL) : 0.000628 , koefisien regresi variabel Non Perfoming Loan (NPL) $\left(\mathrm{X}_{2}\right)$ sebesar 0.000628 . Berarti ada pengaruh positif antara Non PerfomIng Loan (NPL) $\left(\mathrm{X}_{2}\right)$ terhadap Penyaluran Kredit Konsumsi (Y) sebesar: 0.000628, Jika Non Perfoming Loan $\left(\mathrm{X}_{2}\right)$ naik sebesar sebesar 1\%, Maka penyaluran kredit konsumsi (Y) akan naik sebesar 0,06 \% dan jika NPL $\left(\mathrm{X}_{2}\right)$ turun sebesar 1\% maka penyaluran Kredit Konsumsi (Y) akan turun sebesar 0,06\%. dengan asumsi variabel lainnya konstan tidak mengalami perubahan atau tetap (cateris paribus).

B1(CAR): $\quad$-0.045952, koefisien regresi variabel Capital Adequacy Ratio (CAR) $\left(\mathrm{X}_{3}\right)$ sebesar -0.045952. 
Berarti ada pengaruh negatif antara Capital Adequacy Ratio (CAR) $\left(\mathrm{X}_{3}\right)$ terhadap Penyaluran Kredit Konsumsi (Y) sebesar -0.045952, Jika Capital Adequacy Ratio (CAR) $\left(\mathrm{X}_{3}\right)$ naik sebesar sebesar $1 \%$, Maka penyaluran kredit konsumsi (Y) akan naik sebesar $-4,59 \%$ dan jika CAR $\left(\mathrm{X}_{3}\right)$ turun sebesar $1 \%$ maka penyaluran Kredit Konsumsi (Y) akan turun sebesar $-4,59 \%$. dengan asumsi variabel lainnya konstan tidak mengalami perubahan atau tetap (cateris paribus).

Dari uji $\mathrm{F}$ menunjukan Nilai $\mathrm{df}_{1}$ sebesar 3 dan $\mathrm{df}_{2}=\mathrm{n}-\mathrm{k}-1=49-3$ $-1=45$, pada $\alpha=5 \%(0,05)$ diperoleh nilai $\mathrm{F}_{\text {tabel }}=2.84$ nilai $\mathrm{F}_{\text {hitung }}=15.90012051$ nilai $\mathrm{F}_{\text {hitung }}>$ $\mathrm{F}_{\text {tabel }}(15.90012051>2.84)$. maka dapat ditarik kesimpulan bahwa Ho ditolak dan Ha diterima artinya variabel bebas berpengaruh secara serentak terhadap variabel terikat dengan hasil yang signifikan.

\section{Gambar 5. Grafik Uji Pengaruh Simultan (Uji F)}

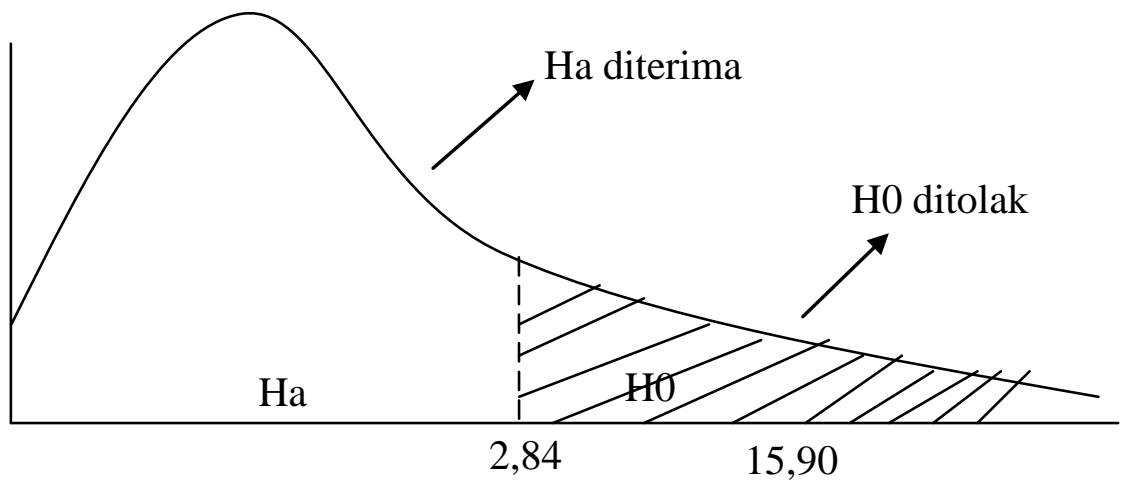

Tabel 2. Hasil Uji Signifikansi Secara Parsial (Uji t)

\begin{tabular}{llllll}
\hline Variabel & Coefficient & Std. Error & t-Statistic & t-Tabel & Prob. \\
\hline DPK & 0.391486 & 0.156396 & 2.503176 & 2.021 & 0.0160 \\
\hline NPL & 0.000628 & 0.037675 & 0.016663 & 2.021 & 0.9868 \\
\hline CAR & -0.045952 & 0.021176 & -2.170056 & 2.021 & 0.0353 \\
\hline
\end{tabular}

\section{Sumber : Data Diolah}

Dana Pihak Ketiga memiliki nilai $t_{\text {hitung }}$ sebesar 2,503176 dengan nilai probabilitas sebesar 0,0160 . Hal ini menunjukan nilai $t_{\text {hitung }}<t_{\text {tabel }}$
$(2,503176<2,021)$ dan nilai probabilitas 0,0160 pada $\alpha=5 \%$ $(0,05)$ maka Ho diterima dan $\mathrm{Ha}$ ditolak. Dengan demikian dapat 
disimpulkan bahwa variabel Dana Pihak Ketiga (DPK) secara parsial berpengaruh secara positif dan signifikan terhadap Kredit Konsumsi di jelaskan pada gambar di bawah ini:

\section{Gambar 6. Kurva Daerah Penerimaan dan Penolakan Ho Untuk Dana Pihak}

\section{Ketiga Pada uji t dua arah}

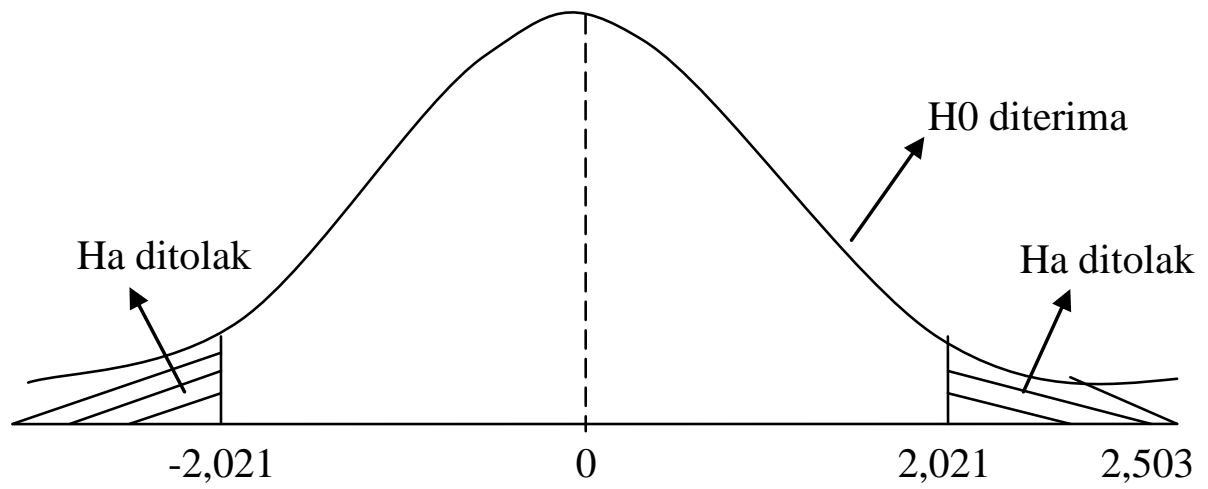

Variabel NPL memiliki nilai $\mathrm{t}_{\text {hitung }}$ sebesar 0,016663 dengan nilai probabilitas sebesar 0,9868. Hal ini menunjukan nilai $t_{\text {hitung }}<t_{\text {tabel }}$ $(0,016663<2.021)$ dan nilai probabilitas 0,9868 pada $\alpha=5 \%$ $(0,05)$ maka Ho ditolak dan Ha

Gambar 7. Kurva Daerah Penerimaan dan Penolakan Ho Untuk Non Perfoming Loan Pada uji t dua arah

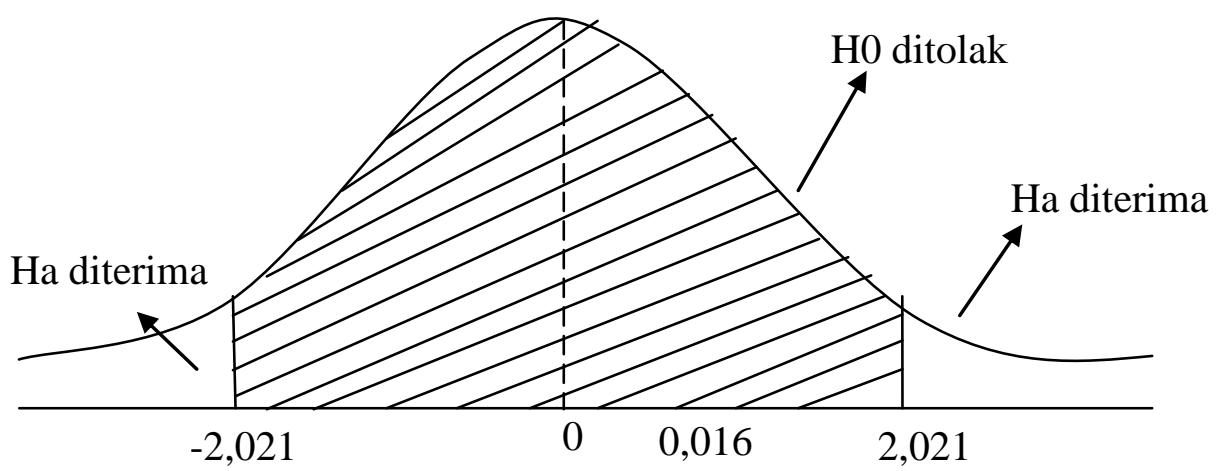


Capital Adequacy Ratio memiliki nilai $t_{\text {hitung }}$ sebesar -2.170056 dengan nilai probabilitas sebesar 0.0353 . Hal ini menunjukan nilai $t_{\text {hitung }}>t_{\text {tabel }}(-$ $2.170056>2,021)$ dan nilai probabilitas 0.0353 pada $\alpha=5 \%$ $(0,05)$ maka Ho ditolak dan Ha diterima. Dengan demikian dapat disimpulkan bahwa variabel CAR secara parsial berpengaruh signifikan dan negatif terhadap Kredit Konsumsi di jelaskan pada gambar 8. di bawah ini:

\section{Gambar 8. Kurva Daerah Penerimaan dan Penolakan Ho Untuk Capital}

\section{Adequacy Ratio Pada uji t dua arah}

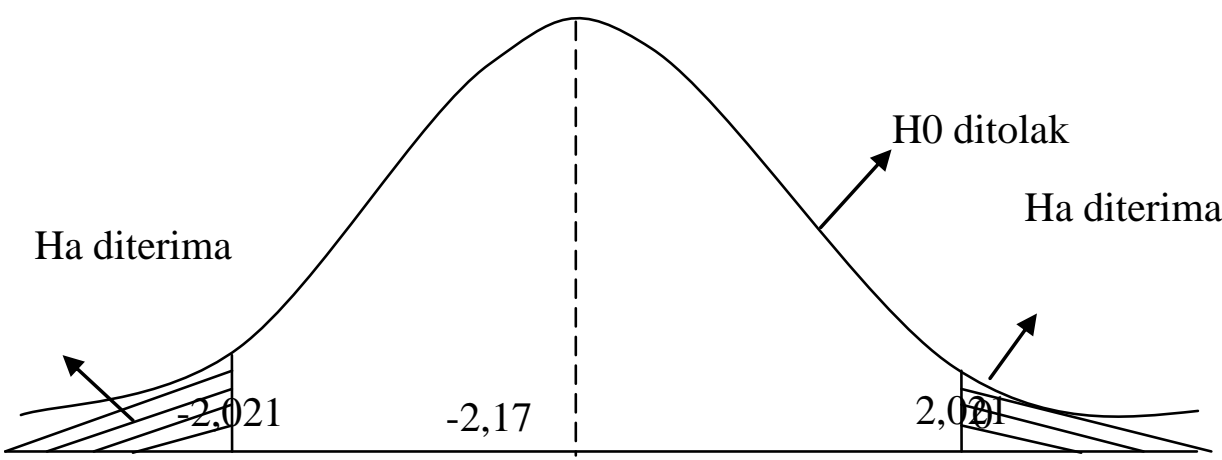

Koe

fisien determinasi $\mathrm{R}^{2}$ sebesar

\section{PENUTUP}

0.545223 atau $54,53 \%$ hal ini menunjukan bahwa kemampuan variabel bebas yang terdiri dari dana pihak ketiga, Non Perfoming Loan, dan Capital Adequacy Ratio dalam menjelaskan variabel terikat Kredit Konsumsi yaitu sebesar 0.545223 atau 54,53\% sedangkan sisanya (1$0.545223=0.454777)$ dijelaskan oleh variabel lain diluar model yang secara implisit tercermin pada variabel pengganggu.
Dari analisis data-data yang sudah ada serta pembahasan yang diuraikan sebelumnya, dapat ditarik kesimpulan sebagai berikut:

Dari tujuh jenis operasional perbankan di Indonesia rata - rata distibusi penyaluran kredit konsumsi terbesar pada Bank umum sebesar $5,46 \%$. Sedangkan rata- rata penyaluran kredit konsumsi terkecil oleh Bank campuran sebesar 3,62 \%. Bank campuran di hadapkan pada tantangan yang tidak ringan sebagai 
akibat dari krisis surat utang subprime mortgage di Amerika Serikat yang mendorong terjadinya gejolak di pasar uang internasional dan meningkatnya harga minyak dunia, sehingga berakibat menurunnya konsumsi masyarakat.

Untuk variabel Dana Pihak Ketiga $\left(\mathrm{X}_{1}\right)_{\text {thitung }}>$ ttabel $(2,503176>$ 2,021), untuk variabel Non Perfoming Loan $\left(\mathrm{X}_{2}\right)_{\text {thitung }}<$ ttabel $(0,016663<2,021)$, Sedangkan untuk variabel Capital Adequacy Ratio $\left(\mathrm{X}_{3}\right)_{\text {thitung }}>$ ttabel $(-2.170056>$ 2,021). Dari Analisa data yang di lakukan secara serentak menunjukkan bahwa variabel Dana Pihak Ketiga (DPK), Non Perfoming Loan (NPL), Capital Adequacy Ratio (CAR) berpengaruh siginifikan terhadap penyaluran kredit konsumsi, dengan hasil uji $\mathrm{F}$ secara simultan yaitu dengan nilai Fhitung $>$ Ftabel $(15.90012051<2,84)$ dan $R$ Square sebesar $51,45 \%$.

\section{DAFTAR PUSTAKA}

Ali, Mashud. 2004. Asset Liability Management: Menyiasati Risiko Pasar dan Risiko
Operasional. Jakarta: PT. Gramedia.

Achmad, T, Kusuno. 2003, Analisis Rasio-Rasio Keuangan sebagai Indikator dalam Memprediksi Potensi Kebangkrutan Perbankan Indonesia. Media Ekonomi dan Bisnis, Vol XV, No 1, Juni, Hal 54-75

Bank Indonesia. 2013. Peraturan Bank Indonesia No. 15/2/PBI/2013, Jakarta

Budiawan. 2008. Analisis Faktor Faktor yang Mempengaruhi Penyaluran Kredit pada Bank Perkreditan Rakyat (Studi Kasus pada BPR di Wilayah Kerja BI Banjarmasin). Tesis Program Studi Magister Manajemen Universitas Diponegoro Semarang.

Dendawijaya,Lukman. 2005. Manajemen Perbankan. Ghalia Indonesia. Bogor

Harefa, Albert N. 2010. Analisis faktor - faktor yang mempengaruhi permintaan kredit konsumsi pada bank umum di indonesia (pendekatan error correction model), Skripsi Fakultas 
Ekonomi,

Universitas

Sumatera Utara, Medan.

Hutagulung, Nasution, 2013.

Analisis Elastisitas Permintaan

Terhadapa Kredit Konsumsi Di

Sumatera Utara. Jurnal

Ekonomi Dan Keuangan.

Jatmiko. 2013. Buku Pedoman

Penulisan Skripsi Dan

TugasAkhir. Fakultas Ekonomi

Dan Bisnis. Universitas

Muhammadiyah Malang.

Kasmir. 2002. Bank dan Lembaga

Keuangan Lainnya. Edisi

Revisi 2002. Jakarta: PT.

Rajagrafindo Persada.

Kasmir. 2008. Manajemen

Perbankan. Edisi Revisi.

RajaGrafindo Persada. Jakarta.

Manurung, Rahardja. 2004.

Pengantar Ilmu Ekonomi. Edisi

Keempat. Lembaga Penerbit

Fakultas Ekonomi Universitas

Indonesia. Jakarta

Sinungan, Muchdarsyah. 2000.

Manajemen Dana Bank, edisi

kedua. Jakarta: Bumi Aksara.

Pratama,B.A. 2010. Analisis Faktor

- Faktor Yang Mempengaruhi

Kebijakan Penyaluran Kredit

Perbankan (Studi Pada Bank
Umum Di Indonesia Peride

Tahun 2005 -2009). Semarang. Retnadi, Djoko. 2006. Perilaku Penyaluran Kredit Bank. Jurnal Kajian Ekonomi

Sari, G.N. 2013. Faktor-Faktor Yang Mempengaruhi Penyaluran Kredit Bank Umum Di Indonesia (Periode 2008.1 2012.2). Jurusan Ekonomi Pembangunan Fakultas Ekonomi dan Bisnis.

Sari, F.A. 2013. Analisis Kinerja Keunagan Dan Perkembangan Penyaluran Kredit Bank Umum Di Indonesia Tahun 2004 - 2010. Jurusan Ilmu Ekonomi Dan Studi Pembangunan Fakultas Ekonomi Dan Bisnis Universitas Muhammadiyah Malang.

Siamat, Dahlan. 2005. Manajemen Lembaga Keuangan:

Kebijakan Moneter dan Perbankan. Jakarta: FE UI.

Sugiyono. 2008. Metode Penelitian Bisnis, Pendekatan Kuantitatif, Kualitatif, dan $R \& D$. Cetakan Keduabelas. Bandung: CV Alfabeta. 
Susilo dkk. 2006. Bank \& Lembaga

Keuangan Lain. Jakarta:

Salemba Empat.

Widarjono, $\quad$ Agus. 2005.

Ekonometrika Teori dan

Aplikasinya, Edisi

Pertama.Yogyakarta: Ekonisia

Akuntansi - Bisnis dan

Manajemen, Vol.9, No.1, April

Widarjono, Agus. 2007.

Ekonometrika Teori dan
Aplikasi untuk Ekonomi dan Bisnis, Edisi Kedua, Cetakan

Kesatu, Penerbit Ekonisia

Fakultas Ekonomi UII

Yogyakarta

Widarjono, 2009.

Ekonometrika, pengantar dan aplikasi. Yogyakarta: Ekonisia Akuntansi-Bisnis dan Manajemen, Vol.9, No. 1, April. 